\title{
NATIVE FAUNA CONSERVATION IN NEW ZEALAND
}

(From Forest and Bird, the Journal of the Forest and Bird Protection Society of New Zealand)

In 1922 the Animals Protection and Game Act set out a list of protected birds, mammals, reptiles and amphibia, and specified that it was illegal to have their skins eggs, and feathers in private possession. As a commentary on the predominance of birds in the New Zealand fauna, the entries in this list under the heading "Birds" filled just short of four pages, whilst under "Mammalia" appeared only the two native bats, under "Reptiles" the tuatara and under "Amphibia" two native frogs.

This Act is still in force.

However, in spite of the improvements in this Act on earlier protective legislation, a steady decline of the more interesting and rare birds continued.

All the causes of this decline are not fully known, but loss of habitat owing to the opening up of the country was a major cause; road-building also inevitably brought doom to some birds, by opening up hitherto impenetrable country to the range of predatory introduced animals.

At the end of the second world war the Wildlife Division of the Department of Internal Affairs was formed. In 1948 the Department sought the advice of a small group of knowledgeable biologists and ornithologists in its work of bird preservation and instituted the Rare Animals Advisory Committee. The Committee early recommended the importance of permanently conserving in the Chatham Island group, South-East Island, which is grazed by stock. This island is the last haunt of the sand-plover and Chatham Island snipe. It is also one of the few remaining habitats of other rare birds such as the Chatham Island petrel. The Trio Islands in Cook Strait, a breeding area of the rare king shag, and one of the homes of the tuatara were islands in a similar category. There is every reason to hope that these islands can be created wildlife refuges.

Consideration has been given also to the status of the kiwi, weka, brown duck, saddleback, king shag, orange-wattled crow, tuatara and native frog. Discussion and subsequent inquiries have indicated that the little grcy kiwis and other species are not in as grave a position as was thought, and 
that at present they are holding their own. Stocks of North Island wekas were taken and placed in the Wellington and Auckland Zoos with the object of building up a breeding stock for release in other areas. Later another wild stock was planted on an island off northern New Zealand, and in an afforestation area in the Wairarapa hills ; further liberations are planned.

In case introduced rats gained access to Hen Island, the last haunt of the North Island saddleback, an experiment undertaken twenty years before to transplant birds was repeated. Birds were transferred to another vermin-free island in the same locality.

The attention of Marlborough residents was drawn to the singularity of the king shag and regular inspections are made of the breeding haunts to keep an eye on the birds. Here again great public interest was aroused and there appears to have been an increase in numbers.

The position of the orange-wattled (South Island) crow and the kakapo has been found to be the least happy of all. No definite trace of the crow being in any numbers has been found, though some time ago it was thought to have been seen in the Te Anua area and at Stewart Island.

There have been few reports of the kakapo this decade; in spite of enjoying strict legal protection, this species by 1948 was reported to be confined to an area south of Milford Sound and to a triangle formed by the Grey, Buller, and Inangahua rivers, a habitat where it was common twenty years ago. Its present status there is unknown. The outlook for these birds is not bright. Some time ago there was a report of a bird on Stewart Island. Occasional reports have come to hand of the presence of kakapo in the $\mathrm{Te}$ Anau region and it is possible, though improbable, that some survive on Kapiti Island. Special expeditions have been and are being made to try to locate colonies.

In the North Island hitherto widespread birds, such as the sub-species of weka, originally had started to vanish from the Wellington area about 1905 ; suddenly about 1930 they went from the centre of the North Island, and about 1938 they commenced to disappear from North Auckland. The birds are to-day practically confined to Poverty Bay.

Because it is possible that the breeding site of the white heron at Okarito could be endangered by milling, all possible support and assistance is being given to the Department of Lands and Survey to continue its notable work in the building up of this colony, and safeguarding its future. 


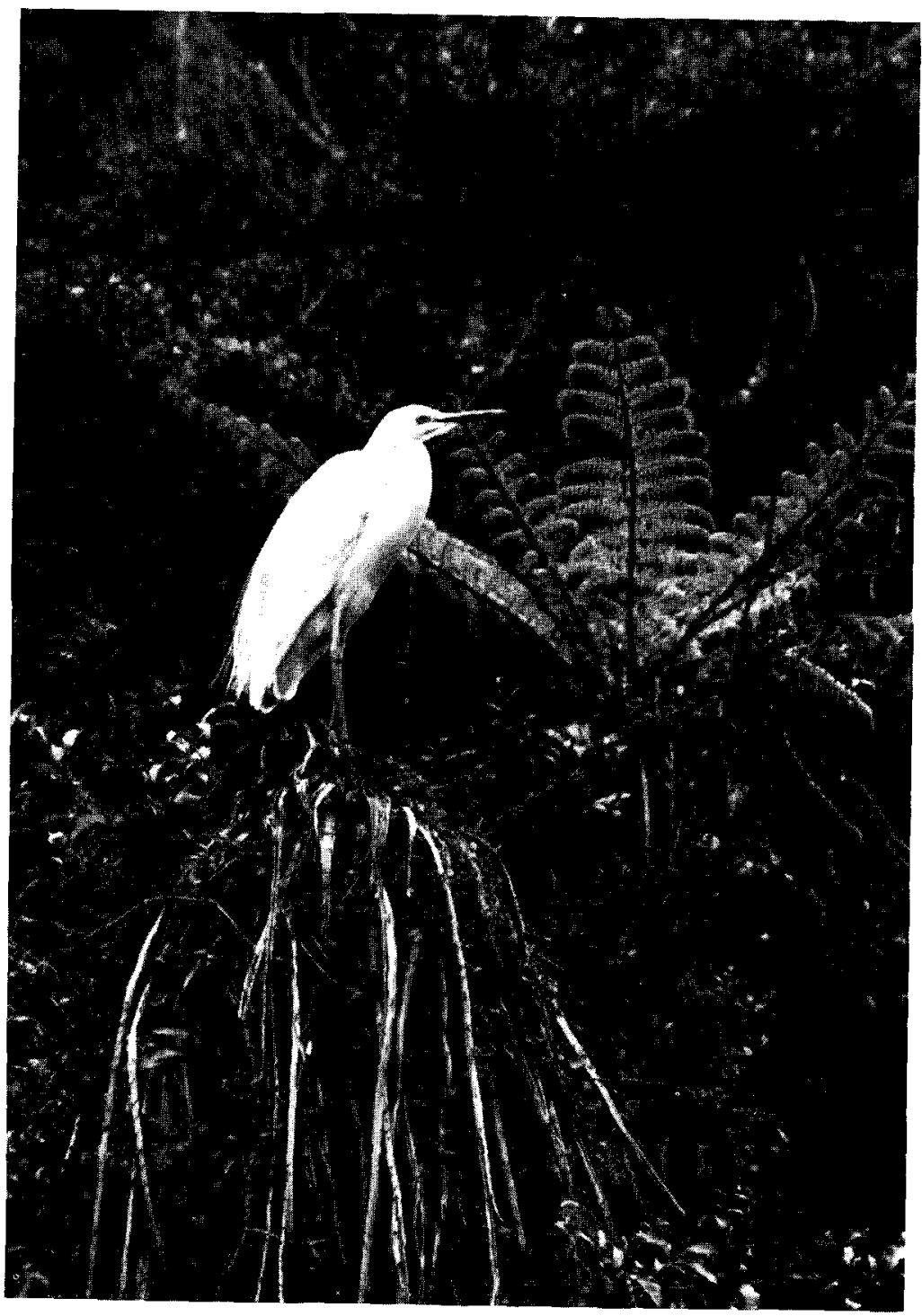

[National Puthicity Studios

NEW ZEALANI) WHITE IIERON. SACRED TO THE MAORIS. 
On Stephens Island conditions for tuataras, and also for the rare Stephens Island frog should improve as a result of an agreement made with the Marine Department, which administers the island. By this agreement the Department of Internal Affairs has fenced the island in two ; one half of it is reverting to its natural state. The head keeper at the island acts as warden ; regular inspections of the area are made by officers.

In all, the Department of Internal Affairs, with the aid of the Committee's suggestions, has done a great deal of direct practical and constructive work towards the conservation of native fauna in the last five years, apart from its well-known work on deer and other introduced animals. To-day the needs of native birds are better understood than at any previous time. The Internal Affairs Department is taking care that the present state of progress will be maintained. 